\title{
Prevalence of Batrachochytrium dendrobatidis in three species of wild frogs on Prince Edward Island, Canada
}

\author{
M. J. Forzán ${ }^{1, *}$, R. Vanderstichel ${ }^{2}$, N. S. Hogan ${ }^{3}$, K. Teather ${ }^{3}$, J. Wood ${ }^{4}$ \\ ${ }^{1}$ Canadian Cooperative Wildlife Health Centre and ${ }^{2}$ Dept. of Health Management, Atlantic Veterinary College, \\ University of Prince Edward Island, 550 University Avenue, Charlottetown, Prince Edward Island, C1A 4P3, Canada \\ ${ }^{3}$ Dept. of Biology, Faculty of Science, University of Prince Edward Island, 550 University Avenue, Charlottetown, \\ Prince Edward Island, C1A 4P3, Canada \\ ${ }^{4}$ Pisces Molecular LLC, 1600 Range St., Suite 201, Boulder, Colorado 80301, USA
}

\begin{abstract}
Chytridiomycosis, caused by the fungus Batrachochytrium dendrobatidis $(B d)$, has resulted in the decline or extinction of approximately 200 frog species worldwide. It has been reported throughout much of North America, but its presence on Prince Edward Island (PEI), on the eastern coast of Canada, was unknown. To determine the presence and prevalence of $B d$ on PEI, skin swabs were collected from 115 frogs from 18 separate sites across the province during the summer of 2009. The swabs were tested through single round end-point PCR for the presence of $B d$ DNA. Thirty-one frogs were positive, including 25/93 (27\%) green frogs Lithobates (Rana) clamitans, 5/20 (25\%) northern leopard frogs $L$. (R.) pipiens, and 1/2 (50\%) wood frogs L. sylvaticus (formerly $R$. sylvatica); 12 of the $18(67 \%)$ sites had at least 1 positive frog. The overall prevalence of $B d$ infection was estimated at $26.9 \%(7.2-46.7 \%, 95 \%$ CI). Prevalence amongst green frogs and leopard frogs was similar, but green frogs had a stronger PCR signal when compared to leopard frogs, regardless of age $(p<0.001)$ and body length $(p=0.476)$. Amongst green frogs, juveniles were more frequently positive than adults $(\mathrm{p}=0.001)$. Green frogs may be the most reliable species to sample when looking for $B d$ in eastern North America. The 1 wood frog positive for $B d$ was found dead from chytridiomycosis; none of the other frogs that were positive for $B d$ by PCR showed any obvious signs of illness. Further monitoring will be required to determine what effect $B d$ infection has on amphibian population health on PEI.
\end{abstract}

KEY WORDS: Batrachochytrium dendrobatidis · Chytrid · Prevalence · Prince Edward Island · Canada $\cdot$ Frogs $\cdot$ Skin swabs $\cdot$ PCR

\section{INTRODUCTION}

Amphibian chytridiomycosis, an infectious skin disease caused by the chytrid fungus Batrachochytrium dendrobatidis $(B d)$, is considered the cause of the decline or extinction of up to 200 species of frogs throughout Europe, Australia, the Americas and Africa (Skerratt et al. 2007). Chytridiomycosis is a reportable disease to the World Organisation for Animal Health (OIE 2008). In Canada, an outbreak was reported in captive frogs in British Columbia (Raverty \& Reynolds 2001). However, there is a paucity of reported mortalities in wild amphib- ians, despite retrospective studies that confirm the presence of $B d$ in northeastern North America since at least 1961 (Ouellet et al. 2005), and a recent survey that found $B d$ in the Northwest Territories of Canada (Schock et al. 2009). Before the present study, there were no reports of $B d$ in captive or wild frog populations on Prince Edward Island (PEI), although the fungus has been identified in specimens from the neighboring Canadian provinces of New Brunswick and Nova Scotia (Ouellet et al. 2005, Canadian Cooperative Wildlife Health Centre [CCWHC] unpubl. data) and the nearby state of Maine, USA (Longcore et al. 2007). 
The main objective of the present study was to determine through PCR on skin swabs (Hyatt et al. 2007) whether $B d$ is infecting frogs on PEI and whether infection rates differ among sites, species, life stage, and sex.

\section{MATERIALS AND METHODS}

Frog collection. Green frogs Lithobates (Rana) clamitans and northern leopard frogs $L$. (R.) pipiens were targeted, as they are the most abundant on PEI (Silva et al. 2003), are the easiest to find and capture, and spend a lot of time in the water, including during hibernation, which makes them more susceptible to $B d$ infection (Longcore et al. 2007). Two wood frogs L. sylvaticus (formerly $R$. sylvatica) were collected fortuitously and were included in the study. The other 3 anuran species present on PEI, spring peeper Pseudacris crucifer, pickerel frog L. (R.) palustris, and American toad Bufo americanus, were not sampled. Sampling was conducted between 5 June and 25 July 2009 at 18 sites across PEI (Fig. 1). Sites were chosen based on recent studies examining amphibian abundance and/or health (Gallant \& Teather 2001, Silva et al. 2003) and information from amphibian enthusiasts regarding breeding sites. Adults, metamorphs (i.e. individuals with forelimbs emerged and sometimes a tail) and occasional tadpoles were captured using dip nets during timed visual searches along the emergent vegetation of the pond. Frogs were placed in individual solid plastic containers with breathing holes, filled with little pond water, and kept in a shady area until all frogs were captured (or until 60 min of searching had elapsed) and swabbing could begin. All equipment was disinfected between captures following established recommendations of The Australian Treatment Abatement Plan (TAP 2006). Briefly, each individual was collected using clean, decontaminated or new disposable gloves; the net and gloves were sprayed with a $1 \%$ sodium hypochlorite disinfecting solution and then rinsed in the pond after each capture. Chest waders, boots, plastic containers and other sampling equipment (e.g. nets, buckets) were similarly disinfected after sampling was completed for a site and, if a second site was sampled on the same day, rinsed in the following pond prior to sampling. Whenever possible, equipment was fully washed in soapy water and disinfected at the laboratory and left to dry overnight.

Swabbing and individual data collection. In total, 115 individuals were sampled: 114 were captured live, swabbed, and released, and 1 (a wood frog) was found dead and tested through histopathology and confirmatory PCR. The swab technique was based on previously established methods (Kriger et al. 2006) and recommendations from the laboratory that conducted the PCR test (Pisces Molecular). Briefly, the frog was restrained with one hand while the other gently ran the cotton swab

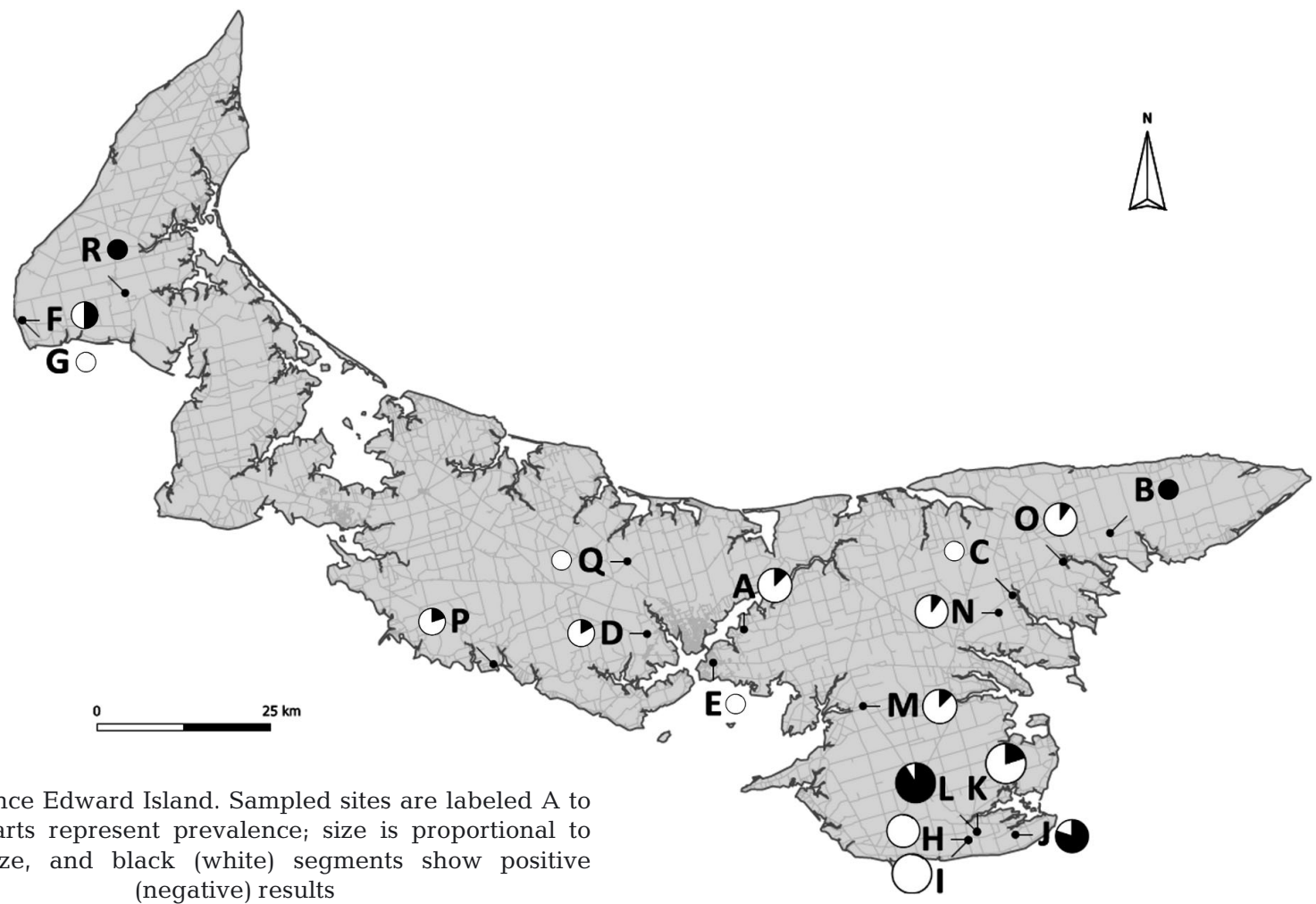

Fig. 1. Prince Edward Island. Sampled sites are labeled A to R. Pie charts represent prevalence; size is proportional to sample size, and black (white) segments show positive (negative) results 
5 times over the ventral surface, the right and left flank, the inner thigh area, and the plantar/palmar surfaces of the feet webbing. Tadpoles were swabbed in the mouth parts only. The same individual performed the swabbing of all frogs and tadpoles, changing gloves between each individual; the collecting tubes containing $70 \%$ ethanol were handled only by a clean person. Individual information including frog species, developmental stage (adult, metamorph, tadpole), and sex (only for green frogs where external characteristics allowed it) was recorded. Frogs were released immediately after swabbing. Re-sampling of the same individual was avoided by only commencing swabbing once all frogs that were to be captured at the site were in plastic containers, and by sampling each site only once. Swabs were transported to the lab and kept at $-4^{\circ} \mathrm{C}$ until shipped to Pisces Molecular for PCR analysis.

PCR test. The liquid in each of the skin swab samples was mixed by repeated pipetting; transference of the total liquid volume into an individual clean microfuge tube followed. Tubes were spun in a microcentrifuge at $\sim 16000 \times g(3 \mathrm{~min})$; the supernatant was drawn off and discarded. Total DNA was extracted using a spincolumn DNA purification procedure (Qiagen DNeasy Blood and Tissue kit).

DNA prepared samples were assayed for the presence of $B d$ ribosomal RNA Intervening Transcribed Sequence (ITS) region by 45 cycle single-round PCR amplification using a published protocol (Annis et al. 2004) modified for greater sensitivity and specificity (J. Wood unpubl.).

PCR reactions were electrophoresed on $2 \%$ agarose gels, post-stained with ethidium bromide, visualized on a $254 \mathrm{~nm}$ ultraviolet light box, and photographed with Polaroid type 667 film.

PCR reactions were scored for the presence or absence of an amplified band of the size expected for the location of the primers in the $B d$ ribosomal RNA ITS region (294 bp), and the intensity of the amplified band qualitatively scored as very strong positive $(+++)$, strong positive $(++)$, positive $(+)$, weak positive $(\mathrm{w}+)$, or no signal/below limit of detection $(-)$. Band intensities for all reactions were independently scored by multiple, trained observers and showed very close correspondence (>95\% identical scores). Band intensities for this $B d$ PCR assay correlate very tightly with independent measurements of zoospore equivalent target sequence DNA copies with a qPCR assay, including equal detection sensitivity (J. Wood unpubl.). The signal from the positive control was used as the standard for a $(+++)$ signal.

Statistical analysis. All p-values were calculated using Fisher's exact test, unless otherwise stated. For statistical purposes, individuals were classified as either adult $(n=79)$ or juvenile $(n=36)$. The juvenile classification included metamorphs $(\mathrm{n}=33$ ) and tadpoles $(n=3)$. Clustering effects of frogs within ponds were analytically adjusted when determining prevalence estimates in Stata10 (Stata 2008) using SURVEY procedures. A linear regression was used to evaluate the effect of size (snout to vent length, SVL) on PCR signal strength.

\section{RESULTS}

In total, 115 frogs from 18 separate sites were swabbed for $B d ; 31$ frogs were positive, specifically 25/93 (27\%) green frogs, 5/20 (25\%) northern leopard frogs, and $1 / 2(50 \%)$ wood frogs (Table 1$)$. Twelve of the 18 sites had at least 1 positive frog. The overall prevalence of $B d$ infection in frogs on PEI was estimated as $26.9 \%(7.2-46.7 \%, 95 \% \mathrm{CI})$.

Prevalence per site was determined by analyzing only those sites where $\geq 5$ frogs were swabbed ( $\mathrm{n}=12$ sites), to reduce inaccuracy due to small sample size. Of these, 2 sites had no positive frogs (average prevalence $=0 \%$ ), the remaining 10 sites showed a dichotomy in prevalence. Seven sites had an average prevalence of $14.5 \%$ (range: $10-20 \%$ ) while the other 3 sites had an average prevalence of $73.6 \%$ (range: 50-91\%; Fig. 2).

Juvenile green frogs were more frequently positive than adults (observed prevalence of $48.5 \%$ versus $15 \%, \mathrm{p}=0.001)$. When accounting for clustering, however, the $95 \%$ CI of the 2 prevalences overlapped (2.7-27.3 versus $4.3-92.7 \%)$, indicating a very strong pond influence (see Ponds $\mathrm{J}$ and L in Table 1). There was no significant difference between the prevalence in green frogs (all age and sex groups) and leopard frogs ( $p=0.863)$, or between prevalence in adult green frogs and adult leopard frogs $(p=0.407)$. There was no difference in prevalence between male and female green frogs $(p=0.265)$.

There was a significant difference in the strength of the PCR signal amongst species: leopard frogs usually had a positive (+) signal while green frogs had a very strong positive $(+++)$ signal $(p<0.001)$. Signal strength was not associated with size of the frog, as evaluated by comparing average SVL $(p=0.476)$.

\section{DISCUSSION}

A distinction between infection with $B d$ (frog carrying the fungus with no ill effects) and actual disease that can cause death (chytridiomycosis) is recognized (Kriger et al. 2007a). In this study, only a single wood frog was diagnosed as having died of chytridiomycosis; it was found dead in a pond, had severe histopatholog- 
Table 1. Lithobates clamitans, L. pipiens and L. sylvaticus. Number of frogs that tested positive for Batrachochytrium dendrobatidis/number of frogs sampled on Prince Edward Island in summer of 2009, by species, developmental stage (adult vs. juvenile [juv.]) and sex. Empty cell = none sampled

\begin{tabular}{|c|c|c|c|c|c|c|c|c|c|c|}
\hline \multirow[t]{3}{*}{ Site } & \multirow{3}{*}{ Juv. } & \multicolumn{3}{|c|}{ - Green frog } & \multirow{3}{*}{ Total } & \multicolumn{3}{|c|}{- Leopard frog } & \multirow{3}{*}{$\begin{array}{c}\text { Wood frog } \\
\text { Adult }\end{array}$} & \multirow[t]{3}{*}{ Total } \\
\hline & & $\longrightarrow$ & —Adult - & - & & Juv. & Adult & Total & & \\
\hline & & Male & Female & Total & & & & & & \\
\hline A & & $1 / 4$ & $0 / 4$ & $1 / 8$ & $1 / 8$ & & & & & $1 / 8$ \\
\hline B & & $1 / 1$ & $0 / 0$ & $1 / 1$ & $1 / 1$ & & & & & $1 / 1$ \\
\hline $\mathrm{C}$ & & & & & & & $0 / 1$ & $0 / 1$ & & $0 / 1$ \\
\hline $\mathrm{D}$ & & & & & & & $1 / 6$ & $1 / 6$ & & $1 / 6$ \\
\hline E & & & & & & $0 / 2$ & & $0 / 2$ & & $0 / 2$ \\
\hline $\mathrm{F}$ & & & & & & $1 / 1$ & $2 / 4$ & $3 / 5$ & $0 / 1$ & $3 / 6$ \\
\hline $\mathrm{G}$ & & $0 / 2$ & $0 / 0$ & $0 / 2$ & $0 / 2$ & & & & & $0 / 2$ \\
\hline $\mathrm{H}$ & $0 / 2$ & $0 / 2$ & $0 / 5$ & $0 / 7$ & $0 / 9$ & & & & & $0 / 9$ \\
\hline I & $0 / 2$ & $0 / 9$ & $0 / 2$ & $0 / 11$ & $0 / 13$ & & & & & $0 / 13$ \\
\hline $\mathrm{J}$ & $5 / 5$ & $3 / 4$ & $0 / 1$ & $3 / 5$ & $8 / 10$ & & & & & $8 / 10$ \\
\hline K & & $2 / 7$ & $0 / 3$ & $2 / 10$ & $2 / 10$ & & & & & $2 / 10$ \\
\hline $\mathrm{L}$ & $10 / 11$ & & & & $10 / 11$ & & & & & $10 / 11$ \\
\hline M & $0 / 3$ & $1 / 1$ & $0 / 4$ & $1 / 5$ & $1 / 8$ & & & & & $1 / 8$ \\
\hline $\mathrm{N}$ & $0 / 3$ & $0 / 5$ & $1 / 2$ & $1 / 7$ & $1 / 10$ & & & & & $1 / 10$ \\
\hline $\mathrm{O}$ & $1 / 7$ & $0 / 2$ & $0 / 1$ & $0 / 3$ & $1 / 10$ & & & & & $1 / 10$ \\
\hline $\mathrm{P}$ & & $0 / 1$ & $0 / 0$ & $0 / 1$ & $0 / 1$ & & $1 / 4$ & $1 / 4$ & & $1 / 5$ \\
\hline Q & & & & & & & $0 / 2$ & $0 / 2$ & & $0 / 2$ \\
\hline $\mathrm{R}$ & & & & & & & & & $1 / 1$ & $1 / 1$ \\
\hline Total & $16 / 33$ & $8 / 38$ & $1 / 22$ & $9 / 60$ & $25 / 93$ & $1 / 3$ & $4 / 17$ & $5 / 20$ & $1 / 2$ & $31 / 115$ \\
\hline
\end{tabular}

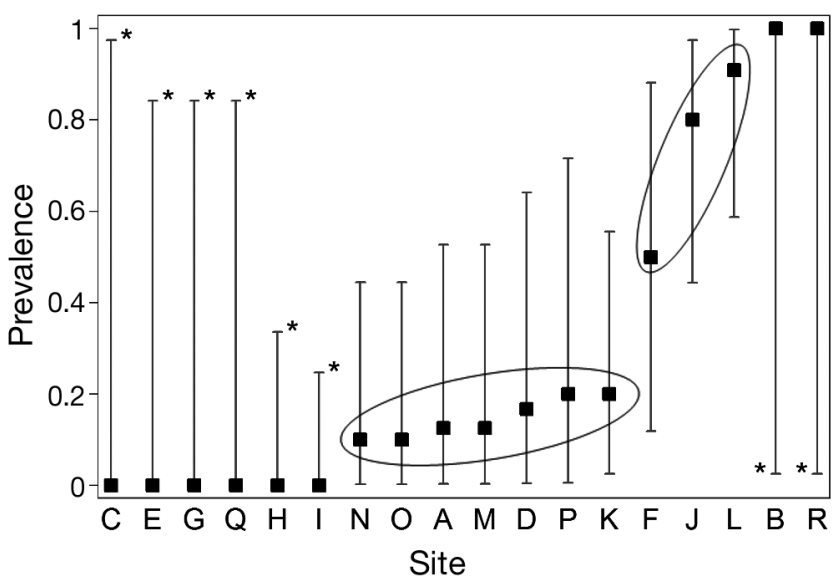

Fig. 2. Prevalence of Batrachochytrium dendrobatidis infection by pond in increasing order with $95 \% \mathrm{CI}$, except for those with 1-sided $97.5 \%$ CI (*). Ponds C, E, G, Q, H, and I had $0 \%$ prevalence. Circles denote the dichotomy between positive ponds with 5 or more samples: N, O, A, M, D, P, and K ranged between 10 and $20 \%$ prevalence, while Ponds F, J, and L ranged between 50 and $91 \%$ prevalence

ical lesions due to the infection with $B d$, no evidence of any other disease, and tested positive for $B d$ through PCR. As no other dead frogs were found and none of the sampled frogs had obvious signs of disease, frogs that were positive for $B d$ by PCR are considered as infected only, and the prevalence estimated and henceforth discussed is for infection with $B d$, not for chytridiomycosis.
Of the total 115 frogs tested, 31 were positive for $B d$ infection: 25/93 (25\%) green frogs, 5/20 (25\%) northern leopard frogs, and 1/2 (50\%) wood frogs, with an overall prevalence on PEI of $26.9 \%$. Green frogs were most frequently captured and swabbed (93/115 frogs) due to their behavior in summer, i.e. the reluctance of adults to leave the ponds long after other frogs have gone back to the grass or woods.

Amongst green frogs, juveniles were more frequently infected than adults. Adults may be protected by acquired immunity (Richmond et al. 2009) and thus may clear or prevent infections more efficiently than juveniles that are naïve to $B d$. Alternatively, and by chance alone, it may be that the ponds where the most juveniles were collected had a true high prevalence of $B d$.

There was a distinct dichotomy in the prevalence at specific sites on PEI: either very low (14.5\%) or very high $(73.6 \%$; Fig. 2). The difference in prevalence at individual sites in this study could be due to microclimatic variables (e.g. temperature, $\mathrm{pH}$, substrate) influencing the survival of $B d$ (Piotrowski et al. 2004, Kriger et al. 2007b, Muths et al. 2008) or to geographic characteristics (e.g. land use, vegetation, proximity to roads) that may influence the ability of the host to manage the infection (Rödder et al. 2008). Alternatively, high prevalence at some sites may simply have been due to the presence of high numbers of juvenile green frogs, as this group had a higher observed prevalence of infection than the adults did. Our relatively small 
sample size prohibited more advanced analyses to evaluate the influence of these potential factors and to differentiate between a site effect and an age effect.

Prevalence in green frogs was not significantly different from that of leopard frogs, but there was a significant difference in the strength of the PCR signal. Green frogs usually had a very strong positive (+++) signal, while leopard frogs mostly had a positive signal (+). Signal strength was not associated with the size of the frog (SVL), but seemed to be associated with the species.

Sampling green frogs may be the most time-efficient way of determining the infection status of a site on PEI and the rest of eastern North America, given their ease of capture and usually high prevalence of infection, confirmed in this study, which is due in part to their hibernating in aquatic environments (Longcore et al. 2007). Determination of the infection status of a site could use OIE recommendations for a 'suitable design prevalence value' when determining freedom from disease for contagious infections (OIE 2006). A $B d$-positive site would thus be expected to have a prevalence of at least $5 \%$. If 55 adult green frogs at a specific site were sampled and all were negative for $B d$, indicating a prevalence of $<5 \%$, with $95 \%$ confidence, the site could be deemed 'free from infection' (OIE 2006).

The significance of $B d$ infection for the frog populations on PEI is uncertain. The 3 published amphibian species abundance surveys for PEI span 4 decades (Cook 1967, Morton et al. 2005, Silva et al. 2003). The last survey, conducted in 2000 (Silva et al. 2003), found no evidence of amphibian decline in the preceding 30 yr. However, it was not a comprehensive survey of PEI. Furthermore, $B d$ may not have been present on PEI at the time of the 2000 study, so the absence of a recorded population decline then does not infer that infection is innocuous. Prevalence of infection with $B d$ in wild frogs in Maine, USA (21.7-26.4\%), was strikingly similar to that found in this study $(26.9 \%)$, and also lacked any recorded population declines (Longcore et al. 2007). In contrast, a $26 \%$ prevalence in eastern Australia (Kriger et al. 2007b) has been accompanied by severe mortality events. Longcore et al. (2007) speculated that perhaps declines have occurred but have gone undetected, that the infection is now endemic and frogs are resistant, or that climatic factors in eastern North America preclude $B d$ from being lethal. Assuming that mortality events in PEI have not simply gone unnoticed or unreported, climatic conditions in this region may prevent the lethal effects of $B d$, either by influencing its growth (Kriger et al. 2007b, Muths et al. 2008) or by enhancing the immune response of the anuran host (Rödder et al. 2008). Perhaps anurans in eastern North America are more resis- tant to the effects of $B d$ through the production of antimicrobial peptides in dermal glands, as are other frog species (Woodhams et al. 2006), or maybe the virulence of $B d$ in North America, which depends on the isolate present (Berger et al. 2005, Retallick \& Miera 2007), is low. Alternatively, declines went unnoticed and infection with $B d$ progressed to a now stable and endemic condition (Retallick et al. 2004). Whether Bd infection of frogs on PEI has an effect on survival will require further studies.

Acknowledgements. We thank W. Petley (Atlantic Veterinary College, AVC) for sharing with us the locations of his favorite frog-catching ponds, D. Weeks (Canadian Cooperative Wildlife Health Centre, CCWHC) and M. Lemon (AVC) for their invaluable assistance in the field, the PEI Dept. of Fish and Wildlife for their highly detailed provincial maps, and 2 anonymous reviewers whose comments improved this manuscript. Funding for this project was provided by the Prince Edward Island Wildlife Conservation Fund and the CCWHC.

\section{LITERATURE CITED}

Annis SL, Dastoor FP, Ziel H, Daszak P, Longcore JE (2004) A DNA-based assay identifies Batrachochytrium dendrobatidis in amphibians. J Wildl Dis 40:420-428

Berger L, Marantelli G, Skerratt LF, Speare R (2005) Virulence of the amphibian chytrid fungus Batrachochytrium dendrobatidis varies with the strain. Dis Aquat Org 68: $47-50$

Cook FR (1967) An analysis of the herpetofauna of Prince Edward Island. Natl Mus Can Bull No. 212

Gallant NS, Teather K (2001) Differences in size, pigmentation, and fluctuating asymmetry in stressed and nonstressed northern leopard frogs (Rana pipiens). Ecoscience 8:430-436

Hyatt AD, Boyle DG, Olsen V, Boyle DB and others (2007) Diagnostic assays and sampling protocols for the detection of Batrachochytrium dendrobatidis. Dis Aquat Org 73: 175-192

> Kriger KM, Hines HB, Hero JM, Hyatt AD, Boyle DG (2006) Techniques for detecting chytridiomycosis in wild frogs: comparing histology with real-time Taqman PCR. Dis Aquat Org 71:141-148

Kriger KM, Ashton KJ, Hines HB, Hero JM (2007a) On the biological relevance of a single Batrachochytrium dendrobatidis zoospore: a reply to Smith (2007). Dis Aquat Org 73:257-260

Kriger KM, Pereoglou F, Hero JM (2007b) Latitudinal variation in the prevalence and intensity of chytrid (Batrachochytrium dendrobatidis) infection in Eastern Australia. Conserv Biol 21:1280-1290

> Longcore JR, Longcore JE, Pessier AP, Halteman WA (2007) Chytridiomycosis widespread in anurans of northeastern United States. J Wildl Manag 71:435-444

Morton LD, Ouellette JM, Prescott WH (2005) A herpetofaunal survey of Prince Edward Island National Park. Preliminary Report for Parks Canada, Sackville, NB

Muths E, Pilliod DS, Livo LJ (2008) Distribution and environmental limitations of an amphibian pathogen in the Rocky Mountains, USA. Biol Conserv 141:1484-1492

OIE (2006) OIE manual of diagnostic tests for aquatic animals. Available at www.oie.int/fr/normes/fmanual/A_00013. htm 
OIE (2008) OIE Report of the meeting of the OIE Aquatic Animal Health Standards Commission, Paris, 3-7 March 2008, 76th General Session. Available at www.oie.int/aac/eng/ FDC\%20reports/Mar\%202008\%20report\%20(English).pdf

Ouellet M, Mikaelian I, Pauili BD, Rodrigue J, Green DM (2005) Historical evidence of widespread chytrid infection in North American amphibian populations. Conserv Biol 19:1431-1440

Piotrowski JS, Annis SL, Longcore JE (2004) Physiology of Batrachochytrium dendrobatidis, a chytrid pathogen of amphibians. Mycologia 96:9-15

Raverty S, Reynolds T (2001) Cutaneous chytridiomycosis in dwarf aquatic frogs (Hymenochirus boettgeri) originating from southeast Asia and in a western toad (Bufo boreas) from northeastern British Columbia. Can Vet J 42:385-386

Retallick RWR, Miera V (2007) Strain differences in the amphibian chytrid Batrachochytrium dendrobatidis and non-permanent, sub-lethal effects of infection. Dis Aquat Org 75:201-207

Retallick RWR, McCallum H, Speare R (2004) Endemic infection of the amphibian chytrid fungus in a frog community postdecline. PLoS Biol 2:e351, doi:10.1371/journal.pbio. 0020351

Richmond JQ, Savage AE, Zamudio KL, Rosenblum EB (2009) Toward immunogenetic studies of amphibian chytridiomycosis: linking innate and acquired immunity. Bioscience 59:311-320

Editorial responsibility: Cynthia Carey, Boulder, Colorado, USA
Rödder D, Veith M, Lötters S (2008) Environmental gradients explaining the prevalence and intensity of infection with the amphibian chytrid fungus: the host's perspective. Anim Conserv 11:513-517

Schock DM, Ruthig GR, Collins JP, Kutz SJ and others (2009) Amphibian chytrid fungus and ranaviruses in the Northwest Territories, Canada. Dis Aquat Org doi:10.3354/ dao02134

Silva M, Hartling LA, Field SA, Teather K (2003) The effects of habitat fragmentation on amphibian species richness of Prince Edward Island. Can J Zool 81:563-573

Skerratt LF, Berger L, Spear R, Cashins S, McDonald KR, Phillott AD, Hines HB, Kenyon N (2007) Spread of chytridiomycosis has caused the rapid global decline and extinction of frogs. EcoHealth 4:125-134

Stata (2008) Stata statistical software, release 10.1. Stata Corporation LP, College Station, TX

TAP (2006) The Australian Treatment Abatement Plan, Background Document. Dept. of the Environment and Heritage, Commonwealth of Australia. Available at http://www.environment.gov.au/biodiversity/threatened/ publications/tap/pubs/chytrid-background.pdf

Woodhams DC, Rollins-Smith LA, Carey C, Reinert L, Tyler MJ, Alford RA (2006) Population trends associated with skin peptide defenses against chytridiomycosis in Australian frogs. Oecologia 146:531-540

Submitted: February 3, 2010; Accepted: May 19, 2010

Proofs received from author(s): June 10, 2010 